\title{
Channel and Perennial Flow Initiation in Headwater Streams: Management Implications of Variability in Source-Area Size
}

\author{
Kristin L. Jaeger · David R. Montgomery • \\ Susan M. Bolton
}

Received: 28 September 2005/ Accepted: 23 April 2007

(C) Springer Science+Business Media, LLC 2007

\begin{abstract}
Despite increasing attention to management of headwater streams as sources of water, sediment, and wood to downstream rivers, the extent of headwater channels and perennial flow remain poorly known and inaccurately depicted on topographic maps and in digital hydrographic data. This study reports field mapping of channel head and perennial flow initiation locations in forested landscapes underlain by sandstone and basalt lithologies in Washington State, USA. Contributing source areas were delineated for each feature using a digital elevation model (DEM) as well as a Global Positioning System device in the field. Systematic source area-slope relationships described in other landscapes were not evident for channel heads in either lithology. In addition, substantial variability in DEM-derived source area sizes relative to field-delineated source areas indicates that in this area, identification of an area-slope relationship, should one even exist, would be difficult. However, channel heads and stream heads, here defined as the start of perennial flow, appear to be
\end{abstract}

K. L. Jaeger

College of Forest Resources, University of Washington,

P.O. Box 352100, Seattle, WA 98195-2100, USA

Present Address:

K. L. Jaeger $(\square)$

Department of Geosciences, Colorado State University,

322 Natural Resources Building, Fort Collins,

CO 80523, USA

e-mail: kljaeger@cnr.colostate.edu

D. R. Montgomery

Earth \& Space Sciences, University of Washington,

P.O. Box 351310, Seattle, WA 98195-1310, USA

S. M. Bolton

College of Forest Resources, University of Washington,

P.O. Box 352100, Seattle, WA 98195-2100, USA co-located within both of the lithologies, which together with lateral expansion and contraction of surface water around channel heads on a seasonal cycle in the basalt lithology, suggest a controlling influence of bedrock springs for that location. While management strategies for determining locations of channel heads and perennial flow initiation in comparable areas could assign standard source area sizes based on limited field data collection within that landscape, field-mapped source areas that support perennial flow are much smaller than recognized by current Washington State regulations.

Keywords Headwater streams - Channel initiation . Perennial initiation $\cdot$ Source area sizes $\cdot$ Seasonal flow characteristics - Forest hydrology

\section{Introduction}

Headwater streams account for most of the drainage network and supply water, sediment, and wood to downstream fish-bearing channels (Gomi and others 2002, May and Gresswell 2003). Headwater streams also serve as critical habitat for aquatic species, some of which do not occupy larger channels (Wilkins and Peterson 2000). Increased pressure on the water and sediment regimes in headwater systems as a result of land use activities such as timber harvest and road building can impact headwater channels as well as the downstream network (Wemple and others 1996, Jones and others 2000, LaMarche and Lettenmaier 2001, Gomi and others 2004). It can therefore prove beneficial to restrict land-use activities around headwater streams. However, knowledge of the upstream extent of headwater streams, whether defined by the headward extent of channel systems or the uppermost point of perennial 
flow, is limited if only because the start of the channel network can be inaccurately depicted on topographic maps (Montgomery and Foufoula-Georgiou 1993). Drainage density, and the upstream extent of perennial flow, vary between regions as a result of different climatic regimes, natural landscape characteristics (e.g., topography and geology), and land-use impacts (Montgomery and Dietrich 1988, 1989, Prosser and Abernethy 1996, Gandolfi and Bischetti 1997, Tucker and Bras 1998, Smakhtin 2001).

Field identification of the headward extent of the physical drainage network and estimation of the transition between seasonal and perennial flow is costly in terms of both time and labor. In the particular case of perennial streams, which in many regions are protected under State forest practice regulations, the management strategy for identifying the headward extent of these streams in the absence of existing field data tends to rely on setting a minimum drainage area required to support perennial flow that is specific to the climatic region (e.g., WFPB 2002). The implications of carrying out land use activities based on inaccurate identification of channel network extent are both ecologic and economic. There are potential adverse impacts to the stream ecosystem in the event that streams exist higher on the hillslope than what is expected based on the minimum contributing area. Also, there is the potential economic loss from restricted land use in headwater areas where streams are thought to exist, but in reality begin lower on the hillslope. Consequently, there is inherent utility to simple methods that accurately represent the extent of natural stream systems.

Channel-initiation processes can be mathematically described through exceedance of an erosion threshold specific to the particular mechanism controlling channelinitiation (e.g., overland flow, shallow landsliding, and seepage erosion) (Dietrich and others 1992, 1993, Montgomery and Dietrich 1994). Such models predict systematic inverse source area-slope relationships that correspond reasonably well to field-based studies where landsliding and overland flow are the dominant controls on channel head locations (Abrahams 1980, Montgomery and Dietrich 1989, 1994, Dietrich and others 1993, Prosser and Abernethy 1996, Bischetti and others 1998, Vandekerckhove and others 2000). These channel-initiation models that predict inverse source area-slope relationships use drainage area as a surrogate for discharge under the assumption that flowpaths follow the ground-surface topography. However, in other landscapes, area-slope relationships have not been present, specifically because of subsurface flow processes and underlying bedrock characteristics controlling channel head locations (Abrahams 1980, Dietrich and others 1987), the coupling of a low sample size, existence of roads upslope of the channel head, and difficulties in accurately determining the source area size (Bischetti and others 1998), and destructive landuse practices that result in increased vulnerability of the hillslopes to erosion regardless of the location in the landscape (Prosser and Soufi 1998).

In the specific case of bedrock controls on channel head locations where bedrock flowpaths dominate subsurface flow (e.g., Montgomery and others 1997, 2002, Freer and others 2002, McDonnell 2003), the discharge may not scale with the topographically defined drainage area and an areaslope relationship would not be expected to exist for channel head locations. Based on a limited data set for channel heads underlain by basalt that showed no systematic area-slope relationship, Dietrich and others (1987) argued that the location of channel heads, controlled by the fractured nature of the local bedrock, were independent of slope and area.

Despite the adoption of land-use guidelines and regulations centered on the concept of a critical area necessary to support a stream channel, there have been few direct tests of the assumed critical drainage area values adopted in environmental management. The first objective of this study was to field identify and map the headward extent of the channel network and determine whether source-area relationships can accurately predict channel head locations in two different lithologies in southwestern Washington State. In the basalt lithology, it was expected that fractures in the bedrock would control channel head locations and no source area-slope relationship would be present. In the sandstone lithology, it was expected that a source areaslope relationship would be present under the assumption that drainage area is a reasonable surrogate for discharge. The second objective of this study was to identify the point where surface water flow transitions from seasonal to perennial within the channels underlain by the two lithologies. The farthest upslope extent of perennial flow was field-mapped and the upslope source area sizes were calculated. Additional observations were also made on seasonal changes in surface water expression in headwater streams underlain by the two different lithologies.

\section{Study Area}

The study sites were located in the Willapa Hills and Black Hills regions of the Washington Coast Range in moderate to steep terrain actively managed for timber harvest by the Washington State Department of Natural Resources (Figure 1). Study sites consisted of a ridgeline with hollows that drained into first-order streams occurring downslope. The hollows extended along the length of the ridgeline. The study sites did not include roads that had been constructed downslope of the ridgeline. The number of first-order streams evaluated at each study site is listed in 
Fig. 1 Map of study sites in southwest Washington State. 1: Black Hills Region, Basalt sites $1 \mathrm{Ba}, 1 \mathrm{Bb}, 1 \mathrm{Bc}$. 2: Willapa Hills Region, Sandstone site 2S. 3: Willapa Hills Region, Basalt sites $3 \mathrm{Ba}, 3 \mathrm{Bb}$, and sandstone site $3 \mathrm{~S}$

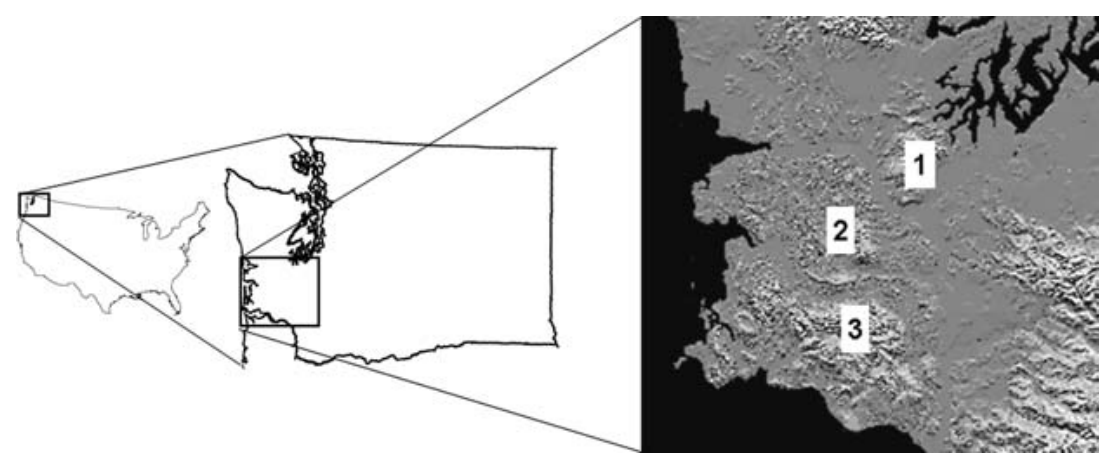

Table 1 Study site summary characteristics ${ }^{\mathrm{a}}$

\begin{tabular}{|c|c|c|c|c|c|c|c|}
\hline Site & $\begin{array}{l}\text { Location (township, } \\
\text { range, section) }\end{array}$ & $\begin{array}{l}\text { Area of } \\
\text { sites } \\
\left(\mathrm{km}^{2}\right)\end{array}$ & $\begin{array}{l}\text { Average } \\
\text { annual } \\
\text { precip. }(\mathrm{cm})\end{array}$ & $\begin{array}{l}\text { No. } \\
\text { channel } \\
\text { heads }\end{array}$ & $\begin{array}{l}\text { Channel } \\
\text { head elevation } \\
\text { range }(\mathrm{m})\end{array}$ & $\begin{array}{l}\text { Ridgeline } \\
\text { elevations } \\
(\mathrm{msl})\end{array}$ & Lithology \\
\hline $1 \mathrm{Ba}$ & T17N, R3W, S6 T17N, R4W, S1 & 0.5 & $228-277$ & 17 & $213-341$ & 443 & Basalt \\
\hline $1 \mathrm{Bb}$ & $\mathrm{T} 18 \mathrm{~N}, \mathrm{R} 3 \mathrm{~W}, \mathrm{~S} 31$ and $\mathrm{S} 32$ & 0.2 & $228-277$ & 5 & $354-448$ & 559 & Basalt \\
\hline $1 \mathrm{Bc}$ & T18N, R3W, S28 and S33 & 0.1 & $228-277$ & 4 & $206-269$ & 323 & Basalt \\
\hline $3 \mathrm{Ba}$ & $\mathrm{T} 13 \mathrm{~N}, \mathrm{R} 8 \mathrm{~W}, \mathrm{~S} 28$ and S33 & 0.3 & $243-280$ & 13 & $195-448$ & 480 & Basalt \\
\hline $3 \mathrm{Bb}$ & T12N, R8W, S10 & 0.3 & $243-280$ & 7 & $159-344$ & 405 & Basalt \\
\hline $2 \mathrm{~S}$ & T14N, R6W, S31 T14N, R7W, S36 & 0.6 & $226-229$ & 17 & $190-252$ & 263 & Sandstone \\
\hline $3 \mathrm{~S}$ & $\mathrm{~T} 12 \mathrm{~N}, \mathrm{R} 8 \mathrm{~W}, \mathrm{~S} 10$ & 0.2 & $243-280$ & 18 & 159-344 & 405 & Sandstone \\
\hline
\end{tabular}

${ }^{a}$ Average annual precipitation was determined for each study site using modeled data from the Oregon State University PRISM (Parameterelevation Regressions on Independent Slopes Model) project (see Daly and others 1994). The range of precipitation values take into account the range of elevations occurring at a given study site

Table 1. Average hillslope gradients ranged between $20 \%$ and $60 \%$. Tree stand ages were approximately 50 years at all study sites. Soils were mapped as loam and silt loams with similar soil properties. Soil depths of approximately $1-1.5 \mathrm{~m}$ decrease to about $0.5 \mathrm{~m}$ near ridgelines (Ness 1958, Pringle 1986). The study sites lie beyond the southern extent of the Cordilleran Ice sheet (Logan 1987a, Lasmanis 1991).

Both the Willapa Hills and Black Hills region are characterized as relatively smooth and rolling topography with mountain tops that are rounded and tree-lined. Elevations within the Willapa Hills region reach up to 790 m above sea level (USGS 1986, 1994a, 1994b) and $810 \mathrm{~m}$ above sea level in the Black Hills region (USGS 1981, 1993). Precipitation is rain dominated, with high stream flows during long-duration, low-intensity rain events between November and March (Climate Summaries Data 2003). Snow accumulation is not a major influence on the hydrologic regime. Using data from the Oregon State University PRISM (Parameter-elevation Regressions on Independent Slopes Model) project, the 1971-2000 normal annual precipitation for the study sites in the Black Hills region ranges between 240 and $277 \mathrm{~cm}$ and between 230 and $280 \mathrm{~cm}$ for the Willapa Hills region. These data were generated from regional regressions of precipitation point values with basin elevation, slope, aspect, and temperature (Daly and others 1994).

This study included a total of seven sites underlain by two primary geologic formations: marine sedimentary bedrock and basalt (Figure 1, Table 1). Two sites (2S and $3 \mathrm{~S})$ were located within the sedimentary lithology; five sites $(1 \mathrm{Ba}, 1 \mathrm{Bb}, 1 \mathrm{Bc}, 3 \mathrm{Ba}$, and $3 \mathrm{Bb})$ were located within the basalt lithology. Site $2 \mathrm{~S}$ is mapped within the Astoria Formation, a poorly cemented, Miocene, marine silty sandstone (Logan 1987b). Observations from rock outcrops near $2 \mathrm{~S}$ reveal that the bedrock is medium-grained, massive, and poorly lithified. Site $3 \mathrm{~S}$ is mapped as the lower McIntosh Formation, another poorly cemented Miocene marine siltstone and silty sandstone. Outcrops at $3 \mathrm{~S}$ show that the bedrock consists of interbedded layers of fine to mediumcoarse grained sandstone of varying hardness. The remaining sites $(1 \mathrm{Ba}, 1 \mathrm{Bb}, 1 \mathrm{Bc}, 3 \mathrm{Ba}$, and $3 \mathrm{Bb})$ are mapped within the Crescent Formation, a fine-grained Eocene basalt with both pillow and blocky jointed structure (Logan 1987a). The Crescent formation, as seen in road-cut exposures, consists of a hard matrix that is severely fractured.

All of the headwater streams begin within the convergent topography of a hollow or at the base of a valley downslope of a hollow. Channels upstream of their first confluence generally drain less than $1 \mathrm{~km}^{2}$ and are steep, 
with gradients $>15 \%$. The average channel length is about $150 \mathrm{~m}$ from channel head to the first confluence. These channels are less than $1 \mathrm{~m}$ wide, with depths that range from $1 \mathrm{~cm}$ to $0.5 \mathrm{~m}$. For the majority of the streams, the channel is discontinuous from the channel head to its first confluence. At one of the study sites (2S), virtually all of the channels and evidence of overland flow disappear at the bottom of the valley immediately before their confluence with the valley bottom mainstem as a result of declining slopes and increased infiltration where these small tributaries enter the larger valleys.

Based on precipitation data from the closest gage (Olympia, Washington) to the streams that were monitored for seasonal changes in surface water expression, the overall water year 2003 was drier than normal (Climate Summaries Data 2003). Comparing the 2003 monthly precipitation totals to the 1971-2000 normal average monthly precipitation values shows that January, March, and April 2003 received more precipitation than normal $(130 \%$ or $14 \mathrm{~cm}$ more for the 3 months). However, the summer months (June through September 2003) received only $44 \%$ ( $8.8 \mathrm{~cm}$ less) of the normal average precipitation. June, July, and August 2003 were particularly dry, with June and July both receiving only $17 \%(3.7 \mathrm{~cm}$ less and $1.7 \mathrm{~cm}$ less, respectively) of the normal monthly rainfall.

\section{Methods}

Study sites were chosen based on the absence of roads occurring along the hillslope upslope or adjacent to the channel head because the presence of a road can alter the hillslope hydrology, and thereby influence the channel head location as well as seasonal surface water drainage patterns (Montgomery 1994, Wemple and others 1996, LaMarche and Lettenmaier 2001). In addition, study sites needed to be easily accessible, i.e., they did not require passing through a locked gate. To maximize the sample size of the data set, all existing channel heads along the ridgeline at a given field site were mapped. An unpaved ridgetop road was located on the drainage divide upslope of three channel heads at study site $2 \mathrm{~S}$, but inspection revealed that any surface runoff generated from the road was routed along drainage patterns associated with the natural ground surface.

Channel head locations were mapped in the field using a high-resolution Global Positioning System (GPS) (GPS Pathfinder Pro-XRS, Trimble). The accuracy of each GPS point taken was automatically generated as part of the output from the GPS. The mean accuracy for all GPS points taken was $\pm 6.7 \mathrm{~m}$ (standard deviation $5.0 \mathrm{~m}$ ); the median was $5.5 \mathrm{~m}$. For the purposes of this project, a channel head is defined as "the upslope limit of erosion and concentration of flow within steepened banks"
(Montgomery and Dietrich 1989, p. 1909), where a definable bank "must be recognizable as a morphological feature independent of the flow" (Dietrich and Dunne 1993, p. 178). As part of the channel head identification criteria, a continuous channel had to extend for at least $5 \mathrm{~m}$ downstream from the channel head.

Mapped channel heads included both abrupt and gradual morphologies (Montgomery and Dietrich 1989). The abrupt channel heads were characterized by an immediate and obvious topographic break in slope caused by erosion. Channel heads were identified as gradual when the incipient development of the channel head extended over several meters downslope, a situation present at approximately one third of mapped channel heads in both sandstone and basalt bedrock.

The local slope immediately upslope of the channel head was measured along the ground surface using a handheld clinometer. Error associated with slope measurements is estimated to be $\pm 2 \%\left( \pm 1^{\circ}\right)$. The field-measured local slope was compared to the slope derived from the digital elevation model (DEM) by taking the elevation difference between the immediately adjacent upstream and downstream DEM cells and dividing that difference by the cell length. Field observations were used to ascertain whether the channel head was formed by overland flow, landslide failure, or emergent subsurface flow. Overland flow was characterized by signs of concentrated flow upslope of the channel head as evidenced by the presence of debris such as leaves and small twigs piled behind rooted vegetation and plants trained downslope. Channel initiation by landsliding was identified by the presence of recent mass wasting scars. Convergent subsurface flow was identified as the most likely channel initiation process in the absence of indicators for either overland flow or landslide failure, and when flow was observed seeping from the channel head or along the channel bed. In the cases of channelinitiation by convergent subsurface flow, it was not possible to determine whether the mechanism was seepage erosion without a greater understanding of the subsurface hydrologic conditions at each channel head site (Dunne 1980, 1990). The channel head's elevation was calculated in a Geographic Information System (GIS) platform.

A subset of streams mapped within the sandstone and basalt lithologies was monitored on a monthly basis to track seasonal changes in streamflow near the channel head. A total of 16 streams were monitored at the $2 \mathrm{~S}$ sandstone site and 14 streams were monitored at the $1 \mathrm{Ba}$ basalt site. These study sites were chosen for streamflow monitoring because they had the highest number of streams that could be accessed easily from one starting location. Monitoring involved flagging the farthest upslope location of surface water in these streams. Flagged locations of surface water included areas containing continuous or 
discontinuous flow, as well as areas in the channel or on the hillside that were locally inundated. A flagged area could be as small as $1 \mathrm{~m}$ in length. Flagging extended along the upslope perimeter of the wetted area.

Monitoring at $1 \mathrm{Ba}$ and $2 \mathrm{~S}$ began in February 2003 and March 2003, respectively, extending until the second week in September 2003. The monitoring period included the seasonally wettest hillslope conditions, as well as baseflow conditions prior to the start of the fall 2003 rainy season. During summer baseflow, the farthest upslope location of surface water was identified as the stream head and is considered the start of local perennial flow.

It is important to note that the monitored streams underlain by basalt had not received any substantial precipitation for at least a week prior to the late summer August and September 2003 monitoring trips, when stream head locations were identified. However, at the sandstone stream subset, 2 days prior to the September 2003 monitoring trip, the site experienced heavy rain for approximately 5 hours. One day prior to monitoring, it rained again for approximately 2 hours.

The flagged locations of surface water were mapped using tape measurements and compass bearings from an origin point surveyed with a GPS. These locations were digitized in a GIS platform for analysis. In addition, the distances from the channel head to the stream head were measured in GIS. In several of the streams, the farthest upslope location of surface water moved from month to month during the monitoring period. The net migration distance between these locations was calculated for each stream head.

The source areas for the channel head and the stream head were defined as the upslope area draining into each respective feature (Shreve 1969). These areas were delineated under the assumption that flowpaths follow the surface topography downslope and therefore surface topography represents the surface and subsurface drainage divide (Freer and others 2002, McDonnell 2003). Although there is no specific evidence to support or refute this assumption for the study sites, this delineation method was employed as the simplest way to delineate source areas in the absence of information regarding subsurface flow conditions. Source areas were delineated using GIS by manually drawing lines across contours of a 2-m resolution DEM for the 1B sites and a 10-m resolution DEM for the remaining sites.

Under the assumption that hydrologic source areas are a function of surface topography, it was expected that field delineation of the ground surface topography would yield a more accurate estimate of the source area because of the relatively coarse DEM resolution. However, because field mapping each source area was prohibitively time consuming, a subset including the largest and smallest source areas were field mapped and the values were compared to the respective source area value generated by the DEMdelineation method. A total of 25 channel head source area boundaries (13 sandstone, 12 basalt) were field mapped using a high-resolution GPS device. Because GPS-delineated source areas are assumed to represent the most accurate estimate of the "true" source area, analyses in this study used the GPS-delineated value where they existed for a channel head instead of the source area delineated using the DEM.

\section{Statistical Methods}

Statistical analysis included simple linear regression and non-parametric comparison of means tests. The channel head slopes and source areas, both DEM- and GPS-delineated, were $\log$ transformed and analyzed using simple linear regression. Average values of source areas between study sites were compared using analysis of variance (Zar 1999). Differences between stream head migration distances were evaluated using a non-parametric Mann-Whitney test for differences in means (Zar 1999).

The 25 GPS-delineated source area values were compared to the corresponding DEM-generated source area values and a least squares linear regression was fit through the data. Confidence and prediction bands were applied around the best fit line.

\section{Results}

\section{Channel Head Mapping}

A total of 81 channel heads were mapped and source areas delineated in GIS for 80 of them (Table 1). Forty-six channel heads were located within the Crescent basalt formation and 35 channel heads were located in sandstone lithologies, of which 17 were in the Astoria Formation (2S) and 18 were in the lower McIntosh Formation (3S). One source area at $2 \mathrm{~S}$ was omitted because the drainage divide, and thus the source area, were poorly represented on the DEM. Bedrock exposures at or immediately downstream from the channel head were not observed. In virtually all cases, the channels were not continuous downslope from the channel head. Soil pipes were identified both upslope and downslope of a few channel heads at all of the field sites.

No source area-slope relationship is evident when all of the log-transformed source area data (55 DEM-delineated and 25 GPS-delineated) are plotted against slope in a simple linear regression (Figure $2, \mathrm{R}^{2}<0.1$ ) or when the GPS-delineated source areas are plotted alone $\left(\mathrm{R}^{2}=0.06\right)$. Nor is a relationship evident when the data are stratified by 


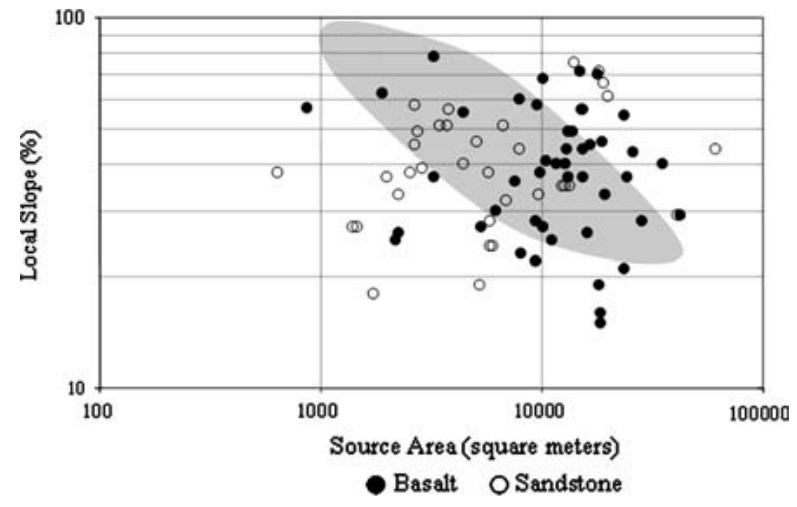

Fig. 2 Channel head locations for all study sites. The shaded area indicates the region for channel head field data from Tennessee Valley, California (Montgomery and Dietrich 1989), which demonstrate a strong area-slope relationship compared to the basalt and sandstone sites included in this study

Table 2 Descriptive statistics for average channel head source areas for all field sites ${ }^{\mathrm{a}}$

\begin{tabular}{|c|c|c|c|c|c|}
\hline & \multicolumn{2}{|c|}{ Sedimentary } & \multicolumn{3}{|l|}{ Basalt } \\
\hline & $2 \mathrm{~S}$ & $3 S$ & 1B & $3 \mathrm{Ba}$ & $3 \mathrm{Bb}$ \\
\hline $\mathrm{N}$ & 16 & 18 & 25 & 13 & 7 \\
\hline Mean & 3894 & 14,055 & 14,636 & 13,626 & 11,253 \\
\hline Median & 3582 & 11,076 & 11,994 & 14,928 & 11,688 \\
\hline Minimum & 1469 & 637 & 2247 & 1913 & 875 \\
\hline Maximum & 6938 & 60,978 & 42,428 & 24,256 & 23,558 \\
\hline Std. Deviation & 1714 & 15,159 & 9766 & 6962 & 8450 \\
\hline $\begin{array}{l}\text { Coefficient of } \\
\text { variation }(\%)\end{array}$ & 0.44 & 1.08 & 0.67 & 0.51 & 0.75 \\
\hline
\end{tabular}

${ }^{\mathrm{a}}$ The 1B sites have been grouped based on their close proximity to each other. All values are in square meters

the two lithologies (basalt $\mathrm{R}^{2}=0.12$, sandstone $\mathrm{R}^{2}=$ $<0.01$ ), or when the sandstone sites are plotted individually $\left(\mathrm{R}^{2}<0.1\right.$ for both $2 \mathrm{~S}$ and $\left.3 \mathrm{~S}\right)$. However, a moderate areaslope relationship exists for two of the three basalt sites when plotted individually. Surprisingly, site 3Ba exhibits a moderate positive relationship $\left(\mathrm{R}^{2}=0.6\right)$ and $3 \mathrm{Bb}$ shows a moderate inverse relationship $\left(\mathrm{R}^{2}=0.5\right)$ more consistent with previous findings. No relationship exists for site $1 \mathrm{~B}$ $\left(\mathrm{R}^{2}<0.1\right)$. In addition to the absence of a strong area-slope relationship, the variability in source areas for the same local slope extends well beyond the range of field data collected by Montgomery and Dietrich $(1988,1989)$, where strong inverse area-slope relationships were shown to exist (Figure 2).

The source area values were log-transformed and their means were compared using Analysis of Variance (Zar 1999). Descriptive statistics for the source areas at each site are presented in Table 2. In general, the sandstone source area sizes were smaller than the basalt source areas $(p=0.001)$; however, this difference largely is driven

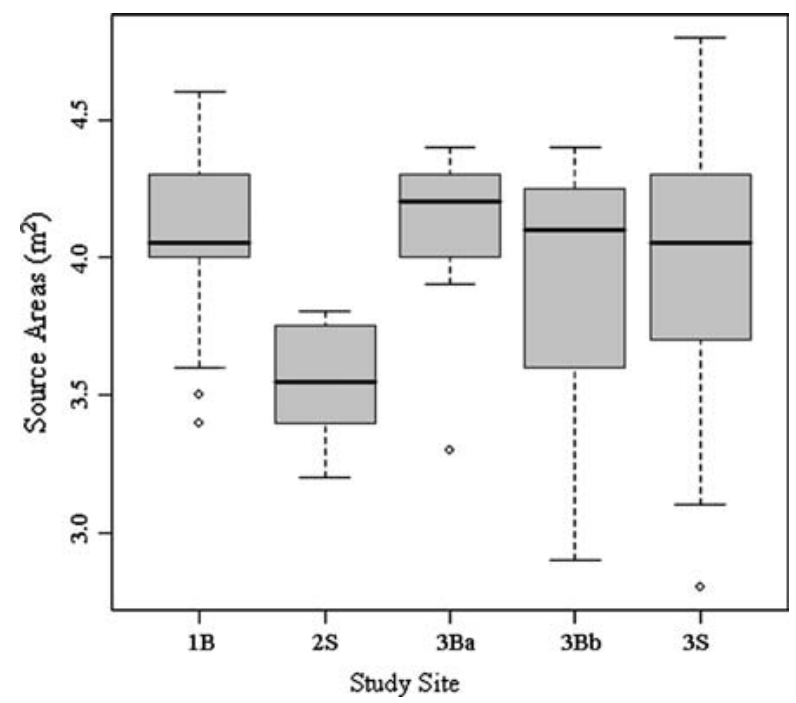

Fig. 3 Boxplot of log-transformed channel head source areas by study site. $2 \mathrm{~S}$ source areas are approximately one third smaller than all other study sites with the exception of $3 \mathrm{Bb}$

by the substantially smaller median source areas at $2 \mathrm{~S}$ (Figure 3). The median source area size at $2 \mathrm{~S}$ is one third of the median source area sizes for all of the other study sites with the exception of $3 \mathrm{Bb}(p<0.0001)$. Because of the scatter in source area values for the $3 \mathrm{Bb}$ site, this is the only site from which the log-transformed source area mean at $2 \mathrm{~S}$ is not significantly different $(p=0.06)$.

There is a weak relationship between the log-transformed DEM-delineation and GPS-delineation methods $\left(\mathrm{R}^{2}=0.60\right)$ and therefore the range within which the source area value is likely to fall is quite large (Figure 4). In general, the DEM delineation tended to overestimate the source area compared to the GPS delineation, and there does not appear to be improved accuracy in source area estimation using the 2-m resolution DEM over the $10-\mathrm{m}$ DEM. The average prediction interval at $95 \%$ confidence was $7800 \mathrm{~m}^{2}$ (standard deviation $=1080 \mathrm{~m}^{2}$ ), which comprises a considerable portion (80-200\%) of the DEM-delineated source area value, depending on the field site.

In addition, slopes derived from the DEM consistently were lower compared to the field-derived slopes. The $10-\mathrm{m}$ DEM generated slopes that were on average $31 \%$ less than field-derived slopes; the 2-m DEM slopes were 12\% less than the respective field slope. However, when regressing the DEM-derived slopes against the field-derived slopes, there is a very poor correlation $\left(\mathrm{R}^{2}=0.3\right.$ for the 2 -m DEM, $\mathrm{R}^{2}<0.001$ for the $10-\mathrm{m} \mathrm{DEM}$ )

\section{Perennial Flow Initiation}

Although the sandstone streams that were monitored experienced several hours of rain during the 2 days prior to 
Fig. 4 Regression: log Global Positioning System (GPS) delineated source area versus $\log$ DEM delineated source area $\mathrm{R}^{2}=0.60$

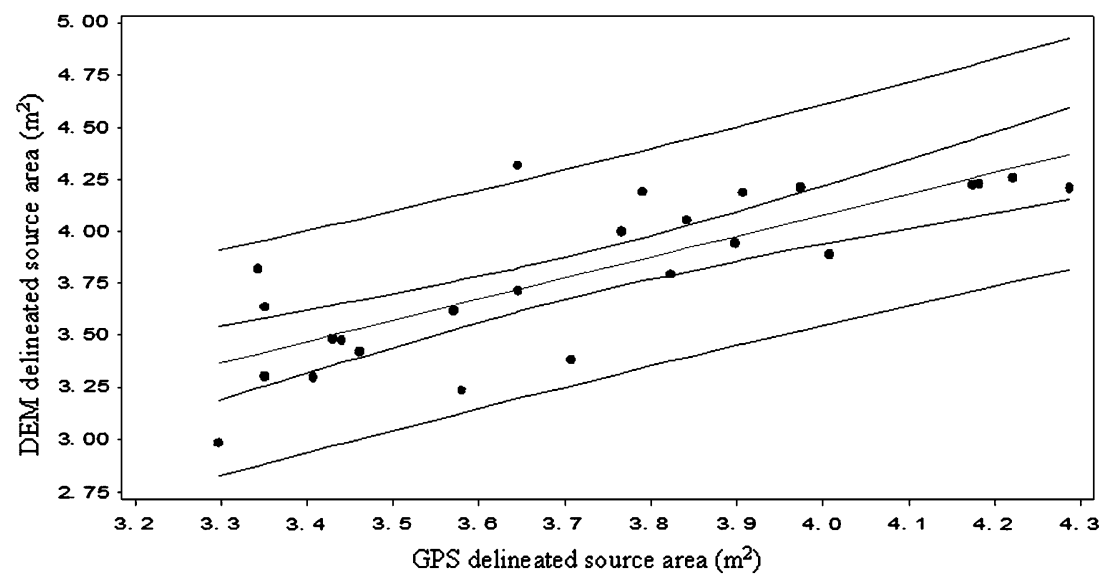

the September 2003 site visit, the farthest upslope locations of surface water were the same as the August 2003 monitoring visit for 15 of the 16 sandstone streams in the monitoring subset. For the one exception, surface water was observed $6 \mathrm{~m}$ upslope of where there had been no flow 1 month earlier.

In virtually all of the streams in both lithologies, flow was spatially discontinuous throughout the monitoring period. However, distinct differences in surface water characteristics and dynamics were observed in streams between the two lithologies. Surface water in the sandstone streams was characterized by a narrow strip of discontinuous flow or standing water less than $1 \mathrm{~m}$ wide either within the channel, at the channel head, or upslope of the channel head. As dry summer conditions developed on the hillslope during the monitoring period from March to September 2003, the upper extent of surface flow on the hillslope would dry up and the farthest upslope location of surface water would migrate in the downslope direction. Conversely, the farthest upslope location of surface water in the basalt streams tended to spread laterally, extending for several meters at the same elevations across the base of the hollow at the location of the channel head.

Net seasonal migration distances for surface flow initiation between lithologies exhibit marked differences. In the basalt streams, the surface water either did not migrate or migrated shorter distances along the hillslope compared to the sandstone streams $(p<0.001)$ (Figure 5). Instead, these wetted areas remained at the same elevations and dried in a lateral direction as summer baseflow conditions developed (Figure 6). In half of the basalt streams, the wetted areas contracted laterally 5 to $24 \mathrm{~m}$, although water continued to emerge at the channel head throughout the summer. The farthest upslope location of surface water migrated longer distances in the streams underlain by sandstone (median migration distance $16 \mathrm{~m}$ ) than in those underlain by basalt (median migration distance $0 \mathrm{~m}$ ). In the sandstone streams, the farthest upslope location of surface

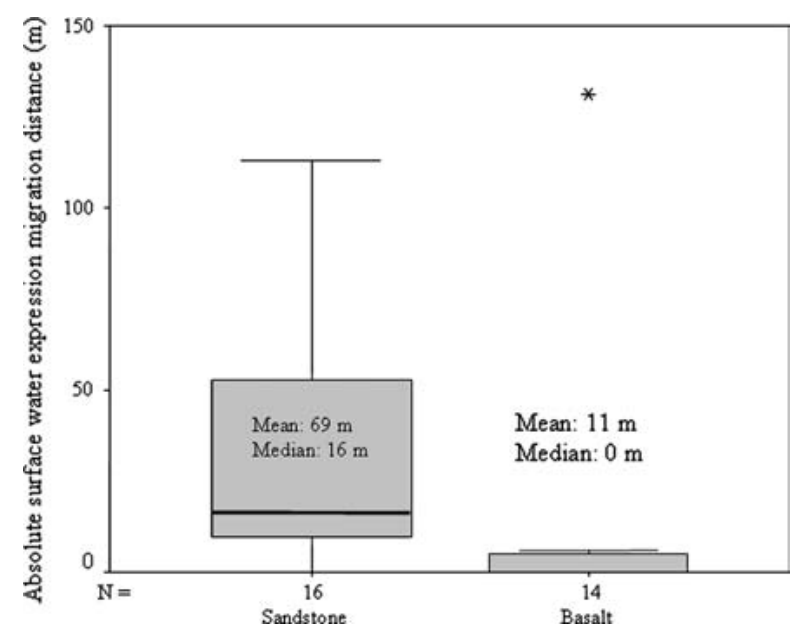

Fig. 5 Migration distances of surface water expression. Two sandstone streams were outliers with migration distances of $345 \mathrm{~m}$ and $398 \mathrm{~m}$. * denotes outlier of 131-m migration distance for one basalt stream

water moved downslope in 14 of the 16 streams. Conversely, more than half of the basalt streams ( 8 of 14) had no seasonal downslope migration of surface water expression. Where downslope migration did occur, distances were $6 \mathrm{~m}$ or less, which were shorter than those observed for the sandstone streams.

Because of the negligible surface water migration distances in the basalt streams, the distances between the locations of the stream head and channel head are significantly larger for sandstone than for basalt lithologies $(p<0.015)$ (Figure 7). The stream head (as defined by the perennial flow initiation point) was downstream of the channel head in half of the 16 sandstone streams that were monitored, whereas these two features were at the same location for all but two of the basalt streams. For six of the remaining eight sandstone streams, the stream head remained at the same location and the other two stream heads were located upslope of the channel head. Two of the sandstone streams went completely dry until their conflu- 
Fig. 6 Lateral contraction of surface water expression around one channel head at $1 \mathrm{Ba}$ site from February to September 2003. Light shading in subsequent panels represents extent of saturated area in February 2003
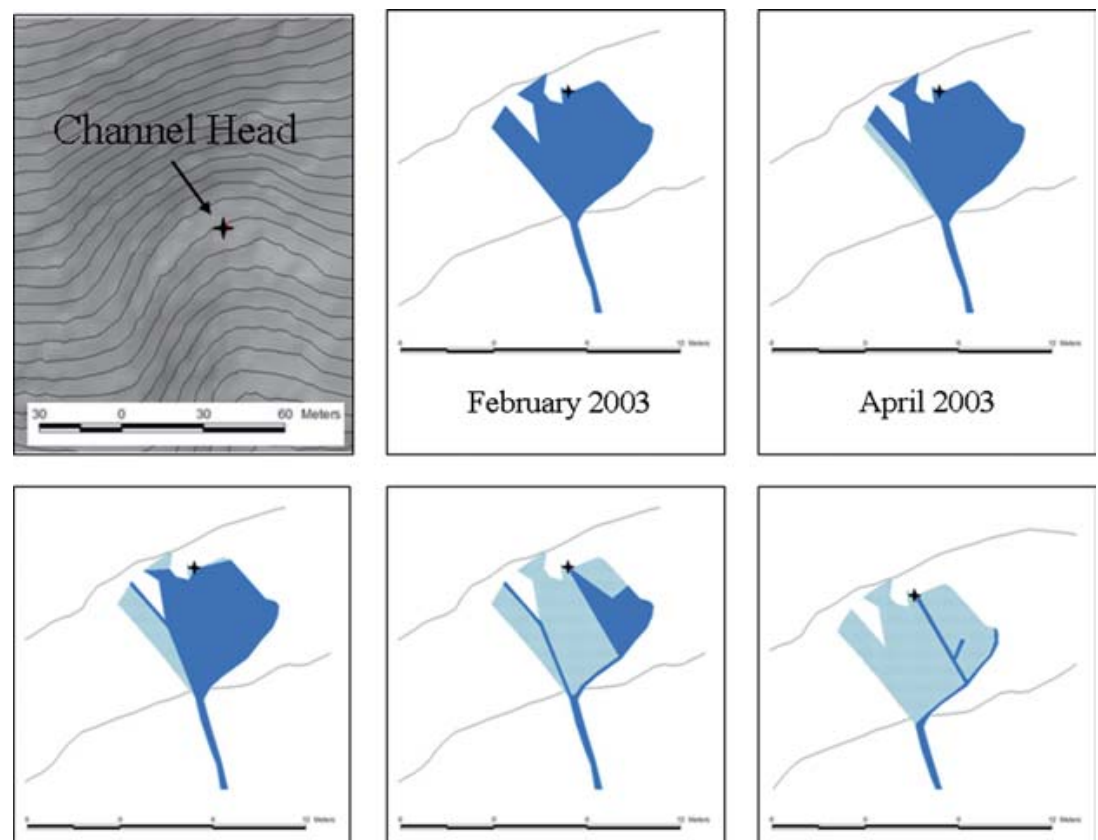

June 2003
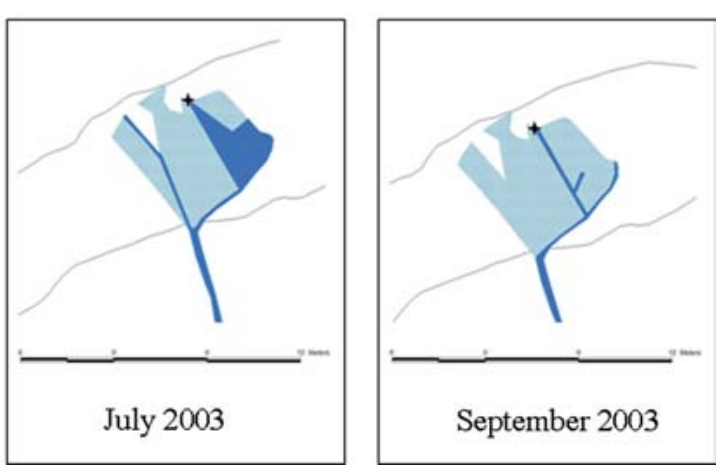

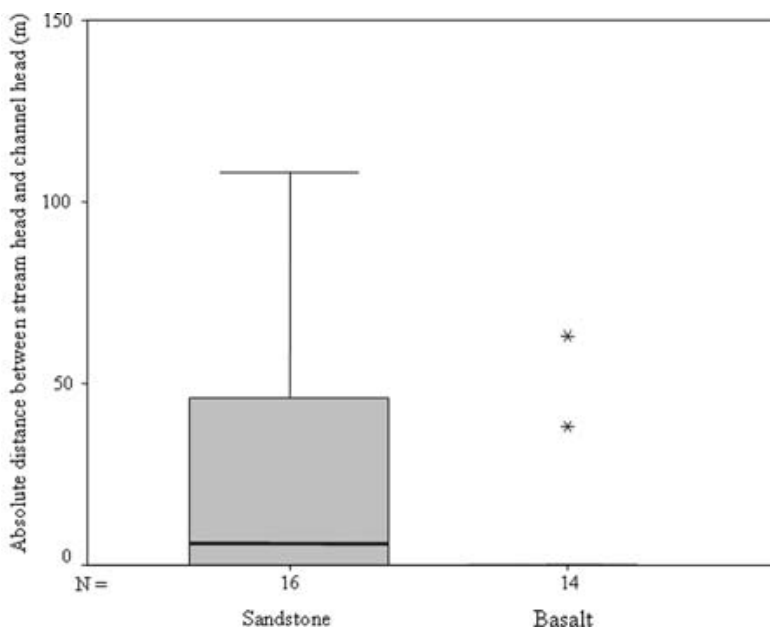

Fig. 7 Stream head distance to channel head. Two outliers for the sandstone streams not shown on this plot are $322 \mathrm{~m}$ and $349 \mathrm{~m}$. *denotes two outliers for the basalt streams of $38 \mathrm{~m}$ and $63 \mathrm{~m}$

ence with the mainstem at the base of the valley more than $320 \mathrm{~m}$ downstream of the channel head. Consequently, the stream head was located a substantially greater distance from the channel head compared to the other streams at this site. Of the remaining two basalt streams where the stream head and channel head were not co-located, one stream head was $38 \mathrm{~m}$ downstream of the channel head, and the other was $63 \mathrm{~m}$ upslope of the channel head. Where surface water was seen upslope of the channel head, there was not enough flow at the stream head to initiate a channel, because there was no evidence of scour or incision within the hollow or along the axis of the valley upslope of the channel head.

Source areas delineated for stream heads are larger in the basalt streams compared to the sandstone streams $(p<0.021)$ (Figure 8). As was the case for channel head source areas, stream head source areas were delineated for 15 of the 16 sandstone streams and all 14 basalt streams. Two of the sandstone streams went completely dry until their confluence with the mainstem at the bottom of the valley, resulting in extremely large stream head source areas compared to the remaining data set for this lithology (Figure 8).

\section{Discussion}

\section{Source Area-Slope Relationships}

The absence of a systematic source area-slope relationship for channel heads underlain by basalt is consistent with field data from other landscapes based on the porous, fractured nature of the bedrock (Dietrich and others 1986, 1987), but the absence of a relationship was not expected for channel heads within a sandstone lithology based on past field studies within similar lithology where such relationships have been observed (Montgomery and Dietrich 1988, 1989, 1992, Prosser and Abernethy 1996, Vandekerckhove and others 2000). It is possible that a lack of an area-slope relationship could be the result of subsurface topography not aligning with surface topography, 


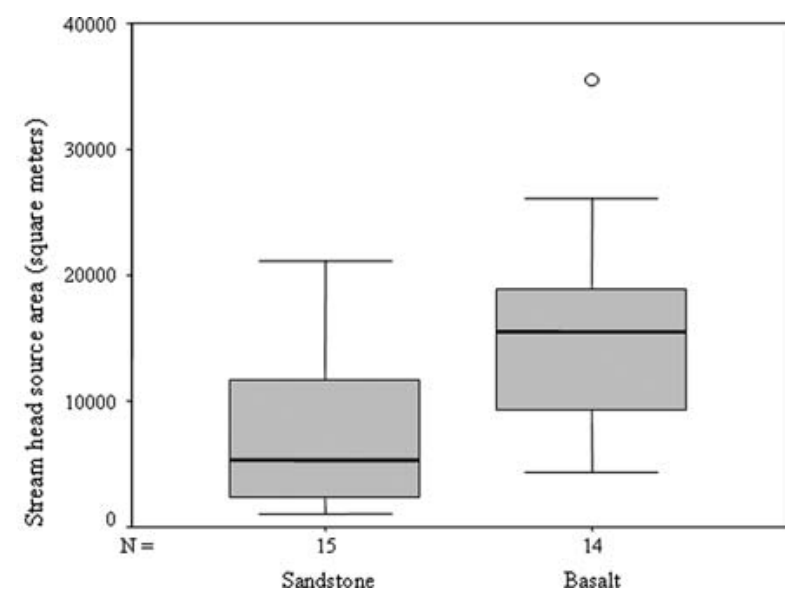

Fig. 8 Stream head source area. Two sandstone outliers not shown in this plot have a source area size of $159,900 \mathrm{~m}^{2}$. The stream head is the same for the two channels heads. $\mathrm{O}$ denotes one basalt stream outlier with a source area size $35,500 \mathrm{~m}^{2}$

e.g., preferential flowpaths in the underlying bedrock that route flow from the hillslope outside of what would be delineated within the source area. There is no information on ground water at any of the study sites that could provide insight regarding the presence or absence of groundwater controls on channel initiation. Conversely, the lack of a source area-slope relationship could result from the narrow range of slopes existing at some of the sites, particularly at the sandstone site, $2 \mathrm{~S}$, where local slope values were between $24 \%$ and $56 \%$. Even where strong source area-slope relationships were identified in previous field studies (Dietrich and others 1986, Montgomery and Dietrich 1988, 1989, 1992), considerable scatter existed for source area values for a particular slope so that identifying a trend required a larger data set across a broad range of slopes $(n=63)$. Consequently, it is possible that the data set of the GPS-derived source areas may be too small ( $n=25)$ to determine whether the apparent lack of an areaslope relationship with the GPS-derived source areas reflects the lack of a relationship or simply that the data set is too small to capture a trend, given the high variability in source area size for a given slope. In addition, as a result of the very weak relationship between the two delineation methods, the variability in DEM-delineated source area values relative to the more accurate GPS-delineated values makes it difficult to determine whether a source area-slope relationship exists using values that are DEM-derived.

\section{Perennial Flow Initiation}

The close proximity of the stream head to the channel head at sites underlain by both lithologies is consistent with findings in recent studies in the Willapa Hills region (Hunter and others 2005). Field identification of the stream head as the start of perennial flow typically is limited to the driest time of the year when baseflow conditions are fully developed. Conversely, the channel head is a morphologic feature independent of the seasonal presence of surface water. In the study area, because of the close proximity of the channel and stream heads, when trying to determine the headward extent of perennial flow in a drainage basin for management purposes, mapping the channel head as a surrogate for the start of perennial flow would allow field surveys to occur during any time of the year instead of during the limited period when baseflow conditions exist. However, this method would be less useful in other landscapes where the channel head and stream head are not co-located, such as headwater channels in the southeastern United States (Rivenbark and Jackson 2004).

It is important to note that because stream head locations are based on a single year of observation, the stability of these features across years was not addressed in this study. Differences in stream head locations between years would have implications on estimates for source areas necessary to support perennial flow. The 2003 period of observation was characterized by a wetter than normal winter and a drier than normal summer, receiving $44 \%$ of the normal precipitation during June, July, and August. Under climatically drier conditions such as the 2003 summer, it is reasonable to speculate that the stream head may be located farther downstream than if observations were made during a wetter summer. However, Hunter and others (2005) reported stable locations for the uppermost extent of surface water, here defined as the stream head, in headwater streams in the Willapa Hills region across 2 years of observations, which were wetter and drier than normal, respectively.

The distinct differences in seasonal changes in streamflow observed between sandstone and basalt streams allow for some inferences regarding the flowpaths of stormflow and baseflow within these lithologies. The stationary position of streamflow in the basalt streams, coupled with the lateral expansion and contraction of the wetted surface area at the same elevation, imply that stormflow and baseflow share similar flowpaths at these sites. However, the downslope migration of streamflow in the sandstone streams implies that stormflow and baseflow flowpaths are not necessarily the same.

The contraction and expansion of the wetted surface area around the channel heads in the basalt streams is similar to observations reported by Anderson and others (1997), where the saturated zone around a channel head in their sandstone catchment indicated that the primary contributors to stream flow were bedrock fractures. Fractures in the basalt bedrock in the streams in the current study potentially could serve as flowpaths, producing a similar phenomenon to that observed elsewhere (Anderson and 
others 1997, Montgomery and Dietrich 2002, Montgomery and others 2002). In addition to bedrock fractures as potential stormflow and baseflow flowpaths, pipeflow was identified in a few of the basalt streams, although changes in flow in the pipes were observed as dry summer hillslope conditions developed. As a result, active pipeflow appears to be higher during the winter season stormflow conditions and remains a minor contributor to surface streamflow during baseflow periods, as found by Montgomery and Dietrich (1995).

In contrast to the basalt streams, virtually all of the sandstone streams displayed large seasonal longitudinal variability in the point of streamflow initiation, indicating that flowpaths contributing to stormflow and baseflow are not necessarily the same. We infer that stormflow follows near-surface flowpaths, leading to seasonal migration in surface water expression (Hewlett and Hibbert 1967), whereas baseflow could be supported by flow either through the soil matrix (e.g., Asano and others 2002) or along bedrock fractures as is hypothesized for the basalt streams, and observed at channel head locations in other sandstone lithologies (Anderson and others 1997, Montgomery and others 1997, 2002).

\section{Management Implications}

From a general land management perspective, a convenient solution for determining the headward extent of the channel network in a landscape with no apparent source areaslope relationship would be to establish a standard source area size based on field data for that landscape. In addition, as a result of the close proximity of the stream head and channel head, identification of the channel head as the start of perennial flow is a management strategy that can be applied to some temperate, humid, forested landscapes. Determining the appropriate representative source area for a given landscape, as well as capturing the variability of source area sizes, would require limited field collection on channel head locations for that region. An example of a conservative management strategy would be to establish the headward extent of headwater streams at a contributing drainage larger than $75 \%$ of all channel heads mapped within a specified landscape based on box plots of source area sizes that are delineated in the field. A less conservative management strategy would set the contributing drainage area to reflect the mean or median source area size for channel head locations in that area.

In the particular case of southwest Washington State, where this study was conducted, current forest practice regulations for estimating the required source area to support perennial flow in the absence of substantiated field data is set at 52,610 $\mathrm{m}^{2}$ (13 acres) (TFWC 1999, WFPB
2002). Based on the findings of this study, the conservative (75\%) management strategy for drainage area required for channel- and perennial-initiation would be established at $9560 \mathrm{~m}^{2}$ (2.4 acres) for streams underlain by basalt and $2010 \mathrm{~m}^{2}(0.5$ acres $)$ for streams underlain by the Astoria sandstone formation. The less conservative (median) management strategy would increase contributing drainage area thresholds to $15,360 \mathrm{~m}^{2}$ (3.8 acres) for the basalt streams and $3030 \mathrm{~m}^{2}(0.7$ acres $)$ for the Astoria sandstone streams. Under these scenarios, the source area size needed to support perennial flow proscribed under current State regulations is overestimated by 3 to 25 times the observed source area sizes.

\section{Conclusions}

Field mapping of channel heads and locations of perennial flow initiation in sandstone and basalt lithologies in the Washington Coast Range reveals that average source area size varies lithologically, but does not follow clear slopedependent trends reported from some other studies (e.g., Montgomery and Dietrich 1988, 1989, 1994, Bischetti and others 1998, Vandekerckhove and others 2000). The poor agreement between DEM-derived source areas and fieldmapped source areas shows that any underlying source area-slope relationship would be difficult to detect or portray from DEM-based analyses. However, it can be interpreted from the observed year-round correspondence of stream heads and channel heads, as well as the spatial characteristics of surface flow within these streams, that the primary flowpaths occur through bedrock springs in at least the basalt study sites. Regardless of the dominant flowpath, limited field surveys of channel initiation locations allow estimation of the minimum source area values required for channel initiation or sustaining perennial flow. The delineation of average source area sizes based on limited field surveys may provide the most practical method for identifying source areas for management applications.

Acknowledgments The Washington Department of Natural Resources provided funding for this project. The authors would like to thank Ellen Wohl for reviewing earlier drafts, and also appreciate the comments of C.R. Jackson and Brian Nerbonne.

\section{References}

Abrahams AD (1980) Channel link density and ground slope. Ann Assoc Am Geogr 70:80-93

Anderson SP, Dietrich WE, Montgomery DR, Torres R, Conrad ME, Loague K (1997) Subsurface flow paths in a steep, unchanneled catchment. Water Resources Res 33:2637-2653

Asano Y, Uchida T, Ohte N (2002) Residence times and flow paths of water in steep unchannelled catchments, Tanakami, Japan. J Hydrol 261:173-192 
Bischetti GB, Gandolfi C, Whelan MJ (1998) The definition of stream channel head location using digital elevation data. 1998. In Kovar K, Tappeiner U, Peters NE, Craig RG (eds.) Hydrology, water resources and ecology in headwaters. International Association of Hydrological Sciences publication no. 248, Pages 545-552

Climate Summaries Data (2003) Available at http://www.wrcc.dri.edu/summary/climsmwa.html. Accessed on September 15, 2003

Daly C, Neilson RP, Phillips DL (1994) A statistical-topographic model for mapping climatological precipitation over mountainous terrain. J Appl Meteorol 33:140-158; http://www.ocs. orst.edu/prism/prism_new.html

Dietrich WE, Dunne T (1993) The channel head. In Beven K, Kirkby MJ (eds.) Channel network hydrology. John Wiley \& Sons Ltd, Pages 175-218

Dietrich WE, Reneau SL, Wilson CJ (1987) Overview: “'zero-order basins" and problems of drainage density, sediment transport and hillslope morphology. In Beschta RL (ed.) Erosion and sedimentation in the Pacific Rim International Association of Hydrological Sciences, Pages 27-37

Dietrich WE, Wilson CJ, Reneau SL (1986) Hollows, colluvium, and landslides in soil-mantled landscapes. In Abrahams AD (ed.) Hillslope processes. Allen and Unwin, London, Pages 361-388

Dietrich WE, Wilson CJ, Montgomery DR, McKean J (1993) Analysis of erosion thresholds, channel networks, and landscape morphology using a digital terrain model. J Geol 101:259-278

Dietrich WE, Wilson CJ, Montgomery DR, McKean J, Bauer R (1992) Erosion thresholds and land surface morphology. Geology 20:675-679

Dunne T (1980) Formation and controls of channel networks. Progr Phys Geogr 4:211-239

Dunne T (1990) Hydrology, mechanics, and geomorphic implications of erosion by subsurface flow. In Higgins CG, Coates DR (eds.) Groundwater Geomorphology, Pages 1-28

Freer J, McDonnell JJ, Beven K, Burns D, Hooper R, Aulenbach B, Kendall C, Peters N (2002) Understanding the spatial and temporal dynamic contributions of subsurface storm runoff at the hillslope scale. Water Resources Res 38:1269-1284

Gandolfi C, Bischetti GB (1997) Influence of drainage network identification method on geomorphological properties and hydrological response. Hydrolog Processes 11:353-375

Gomi T, Sidle RC, Richardson JS (2002) Understanding processes and downstream linkages of headwater systems. BioScience 52:905-916

Gomi T, Sidle RC, Swanson DN (2004) Hydrogeomorphic linkages of sediment transport in headwater streams, Maybeso Experimental Forest, southeast Alaska. Hydrolog Processes 18:667683

Hewlett JD, Hibbert AR (1967) Factors affecting the response of small watersheds to precipitation in humid areas. In Sopper WE, Lull HW (eds.) International symposium on forest hydrology. Pergamon, New York, Pages 275-290

Hunter MA, Quinn T, Hayes MP (2005) Low flow spatial characteristics in forested headwater channels of Southwest Washington. J Am Water Resources Assoc 41:503-516

Jones JA, Swanson FJ, Wemple BC, Snyder KU (2000) Effects of roads on hydrology, geomorphology, and disturbance patches in stream networks. Conserv Biol 14:76-85

LaMarche J, Lettenmaier DP (2001) Effects of forest roads on flood flows in the Deschutes River Basin, Washington. Earth Surf Processes Landforms 26:115-134

Lasmanis RL (1991) The geology of Washington. Rocks Minerals 66:262-277

Logan RL (1987a) Geologic map of the Chehalis River and Westport Quadrangles, Washington. Olympia, Washington Division of Geology and Earth Resources, OFR-87-8, 1 sheet, Scale 1:100,000
Logan RL (1987b) Geologic map of the south half of the Shelton and south half of the Copalis Beach Quadrangles, Washington

May CL, Gresswell RE (2003) Processes and rates of sediment and wood accumulation in headwater streams of the Oregon Coast Range, USA. Earth Surf Processes Landforms 28:409-424

McDonnell JJ (2003) Where does water go when it rains? Moving beyond the variable source area concept of rainfall-runoff response. Hydrolog Processes 17:1869-1875

Montgomery DR (1994) Road surface drainage, channel-initiation, and slope instability. Water Resources Res 30:1925-1932

Montgomery DR, Dietrich WE (1995) Hydrologic processes in a lowgradient source area. Water Resources Res 31:1-10

Montgomery DR, Foufoula-Georgiou E (1993) Channel network source representation using digital elevation models. Water Resources Res 29:3925-3934

Montgomery DR, Dietrich WE (1988) Where do channels begin? Nature 336:232-234

Montgomery DR, Dietrich WE (1989) Source areas, drainage density, and channel-initiation. Water Resources Res 25:1907-1918

Montgomery DR, Dietrich WE (1992) Channel-initiation and the problem of landscape scale. Science 255:826-830

Montgomery DR, Dietrich WE (1994) Landscape dissection and drainage area-slope thresholds. In Kirkby MJ (ed.) Process models and theoretical geomorphology. John Wiley and Sons Ltd., pp 221-246

Montgomery DR, Dietrich WE (2002) Runoff generation in a steep, soil-mantled landscape. Water Resources Res 38:1168-1175

Montgomery DR, Dietrich WE, Heffner JT (2002) Piezometric response in shallow bedrock at C1B: implications for runoff generation and landsliding. Water Resources Res 38:1274-1291

Montgomery DR, Dietrich WE, Torres R, Anderson SP, Heffner JT, Loague K (1997) Hydrologic response of a steep, unchanneled valley to natural and applied rainfall. Water Resources Res 33:91-109

Ness AO (1958) Soil survey of Thurston County, Washington. Soil Conservation Service

Pringle RF (1986) Soil survey of Grays Harbor Area, Pacific County, and Wahkiakum County, Washington. Soil Conservation Service

Prosser I, Abernethy B (1996) Predicting the topographic limits to gully network using a digital terrain model and process thresholds. Water Resources Res 32:2289-2298

Prosser I, Soufi M (1998) Controls on gully formation following forest clearing in a humid temperate environment. Water Resources Res 34:3661-3671

Rivenbark BL, Jackson CR (2004) Average discharge, perennial flow initiation, and channel initiation-small Southern Appalachian basins. J Am Water Resources Assoc 40:639-646

Shreve RL (1969) Stream lengths and basin areas in topographically random channel networks. J Geol 77:397-414

Smakhtin VU (2001) Low flow hydrology: A review. J Hydrol 240:147-186

TFWC (Timber, Fish and Wildlife Committee) (1999) Forests and fish report. Washington State Department of Natural Resources: WAC 222-Forest Practices Rules. Available at http:// www.dnr.wa.gov/forestpractices/rules/forestandfish.pdf Accessed on September 15, 2005

Tucker GE, Bras RL (1998) Hillslope processes, drainage density, and landscape morphology. Water Resources Res 34:2751-2764

USGS (1981) Topographic map of Summit Lake Quadrangle, Washington. 1:24,000

USGS (1986) Topographic map of Menlo Quadrangle, Washington. $1: 24,000$

USGS (1993) Topographic map of Littlerock Quadrangle, Washington. $1: 24,000$

USGS (1994a) Topographic map of East of Raymond Quadrangle, Washington. 1:24,000 
USGS (1994b) Topographic map of Dean Creek Quadrangle, Washington. 1:24,000

Vandekerckhove L, Poesen J, Oostwoud WijDenes D, Nachtergaele J, Kosmas D, Roxo MJ, De Figueredo T (2000) Thresholds for gully initiation and sedimentation in Mediterranean Europe. Earth Surface Processes Landforms 25:1201-1220

Wemple BC, Jones JA, Grant GE (1996) Channel network extension by logging roads in two basins, Western Cascades Oregon. Water Resources Bull 32:1195-1207

WFPB (Washington Forest Practices Board) (2002) Washington State Forest Practices Rules. Section 222-16-030: water typing system, contained in WAC 222-16-definitions and RMAP emergency rule. Washington State Department of Natural Resources. Available at http://www.dnr.wa.gov/forest practices/rules Accessed on September 15, 2005

Wilkins RN, Peterson NP (2000) Factors related to amphibian occurrence and abundance in headwater streams draining second-growth Douglas-fir forests in southwestern Washington. Forest Ecol Manage 129:79-91

Zar JH (1999) Biostatistical analysis. 4th ed. Prentice Hall, New Jersey 